\title{
SURVEI SUB BOTTOM PROFILE (SBP) UNTUK MENGIDENTIFIKASI LAPISAN SEDIMEN PADA MUARA SUNGAI BENGAWAN SOLO MENGGUNAKAN STRATABOX MARINE GEOPHYSICAL INSTRUMENT
}

\author{
Innanda Rizqiani Putri, Dwa Desa Warnana, Firman Syaifuddin \\ Jurusan Teknik Geofisika, FTSP Instittut Teknologi Sepuluh Nopember \\ e-mail: innanda.rp@gmail.com
}

\begin{abstract}
Abstrak. Pengendapan sedimen pada muara Sungai Bengawan Solo cukup besar, hal ini dikarenakan Sungai Bengawan Solo merupakan sungai yang terpanjang di Pulau Jawa. Sungai ini membawa banyak material sedimen sehingga akan terakumulasi pada muara sungai, yaitu pada muara Sungai Bengawan Solo di Pangkah - Gresik. Tujuan dari penelitian ini yaitu untuk menganalisa ketebalan sedimen pada muara Sungai Bengawan Solo dan juga mengidentifikasi kedalaman muara sungai. Ketebalan sedimen dan kedalaman muara dapat diidentifikasi dengan melakukan survei Sub Bottom Profile (SBP). Survei SBP ini memanfaatkan gelombang akustik yang ditembakkan ke bawah permukaan air. Bedasarkan data SBP yang telah dilakukan analisa, maka dapat diperoleh kedalaman sungai berkisar 0.5 - 6 meter, kedalaman muara sungai berkisar 0.3 - 0.8 meter, dan kedalaman muara sungai menuju ke laut berkisar 5 - 7 meter. Berdasarkan peta kontur ketebalan sedimen, dapat dianalisa bahwa ketebalan sedimen sekitar 1 meter.
\end{abstract}

Kata Kunci: gelombang akustik; muara Bengawan Solo; sedimentasi; Sub-Bottom Profile (SBP)

\begin{abstract}
The sedimentation in Bengawan Solo Estuary is significant because it is the longest river in Java Island. It carries substantial material and will be accumulated in Bengawan Solo estuary which is located in Pangkah, Gresik. The aims of this experiment are analyzing the thickness of sediment in Bengawan Solo Estuary and identifying the depth of the estuary. The measurement of Sediment's thickness and Estuary's depth are using the Sub Bottom Profile Survey (SBP). The SBP survey employ the acoustic waves that is propagate into the sea subsurface. Based on the analysis data from SBP, it is known that the depth of river approximately 0.5 - 6 meters, estuary is $0.3-0.8$ meters and estuary towards sea is 0.5 - 7 meters. Based on countour map of sediment's thickness, the sediment thickness of estuary is 1 meter.

Keywords: acoustic wave; Bengawan Solo estuary; sedimentation; ub Bottom Profile Survey (SBP)
\end{abstract}

\section{PENDAHULUAN}

Anak sungai pada sub DAS Bengawan Solo Hulu dan Kali Madiun yang mengalirkan air dari lereng Gunung Merapi, Merbabu, dan Lawu, banyak membawa material sedimen dari hasil erosi pada lereng-lereng tersebut, sehingga mengakibatkan sedimentasi yang tinggi di Sungai Bengawan Solo. Pada tahun 2000, di muara telah terbentuk tiga alur kearah samping dan tidak terjadi perubahan pada saluran utama yang akhirnya tertutup. Ketika salah satu alur kearah samping berubah menjadi lebih panjang dari yang lainnya, ada kecenderungan akan tertutup akibat peningkatan endapan sedimen. Pada saat yang bersamaan, alur yang lain menjadi besar karena ada tambahan debit yang masuk. Muara tersebut telah berkembang membentfuk beberapa alur melalui proses yang sama dan berulang seperti di atas. Proses di atas merupakan proses yang normal dimana terjadi gerusan dan endapan pada dasar sungai dan tidak terpengaruh oleh perubahan akibat proses yang terjadi di pantai. Sehingga pada penelitian ini akan dilakukan survei Sub Bottom Profile (SBP) dengan tujuan untuk menganalisa ketebalan sedimen pada muara Sungai Bengawan Solo, yaitu yang terletak di Pangkah, Gresik, Jawa Timur. Ketebalan sedimen didapatkan dengan menggunakan gelombang akustik pada alat instrument geofisika, yaitu Stratabox.

Penelitian ini bertujuan untuk menganalisa ketebalan sedimen pada muara Sungai Bengawan Solo. Selain itu tujuan dari penelitian ini yaitu untuk memetakan kedalaman sungai - muara Sungai Bengawan Solo, sehingga output dari penelitian ini akan didapatkan peta kedalaman air sungai dan juga peta sebaran ketebalan sedimen. 
Metode geofisika yang cocok untuk menganalisa ketebalan sedimen dan kedalaman sungai Bengawan Solo adalah Sub Bottom Profile (SBP), metode ini merupakan metode seismik dangkal dengan memanfaatkan gelombang akustik. Penetrasi kedalaman metode ini mencapai 40 meter dengan frekuensi 2-10 kHz.

\section{TINJAUAN PUSTAKA}

\section{Sedimentasi pada Muara Sungai Bengawan Solo}

Muara sungai merupakan bagian hilir sungai yang berhubungan dengan laut. Fungsi dari muara sungai ini sebagai tempat pengeluaran atau pembuangan debit sungai terutama pada waktu banjir. Muara sungai mempunyai nilai yang ekonomis yang penting karena dapat berfungsi sebagai alur penghubung antara laut dan daerah daratan. Selain itu, muara sungai banyak dimanfaatkan sebagai lokasi pelabuhan dan memegang peranan penting dalam masalah instrusi air laut. Berkurangnya fungsi muara, baik sebagai saluran debit banjir maupun untuk alur pelayaran, disebabkan oleh sedimentasi. Sedimentasi pada muara mempengaruhi morfologi muara. Ada tiga faktor yang menentukan bentuk dari muara sungai, yaitu gelombang laut, debit sungai, dan pasang surut air laut.

Sungai Bengawan Solo merupakan sungai terpanjang di Pulau Jawa, mengalir dari pegunungan Sewu di Selatan Surakarta, ke Laut Jawa di Utara Surabaya melalui alur sepanjang $\pm 600 \mathrm{~km}$. Anakanak sungai pada sub DAS Bengawan Solo Hulu dan Kali Madiun yang mengalirkan air dari lereng Gunung Merapi, Merbabu, dan Lawu, banyak membawa material sedimen dari hasil erosi pada lereng-lereng tersebut, sehingga mengakibatkan sedimentasi yang tinggi di Sungai Bengawan Solo. (BBWSBS, 2012)

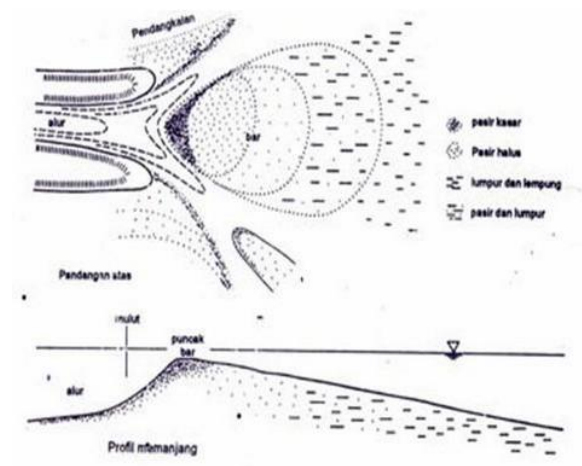

Gambar 1. Tipe Muara yang Didominasi oleh Aliran Sungai, Seperti yang Terjadi Pada Muara Sungai Bengawan Solo (Amri, Ulil, 2016).

Untuk mengatasi masalah sedimentasi yang terjadi di Selat Madura, pemerintah Belanda telah membuat sudetan sungai ke arah Utara melalui daerah rawa menuju Laut Jawa, menghubungkan Sungai Bengawan Solo dengan laut disebelah Timur perkampungan nelayan Ujung Pangkah pada tahun 1890-an. Sampai saat, ini arah (aligment) saluran tersebut masih tetap seperti kondisi awal dikarenakan oleh material lempung padat yang terdapat di daerah rawa tersebut, tetapi telah terjadi perubahan di muara sungai. Pada sekitar tahun 1922, telah terjadi perubahan muara sepanjang $9 \mathrm{~km}$ kearah Utara sepanjang saluran memotong endapan pasir dangkal sampai ke garis pantai. Pada tahun 2000, di muara telah terbentuk tiga alur kearah samping dan tidak terjadi perubahan pada saluran utama yang akhirnya tertutup. Ketika salah satu alur kearah samping berubah menjadi lebih panjang dari yang lainnya, ada kecenderungan akan tertutup akibat peningkatan endapan sedimen. Pada saat yang bersamaan, alur yang lain menjadi besar karena ada tambahan debit yang masuk. Muara tersebut telah berkembang membentuk beberapa alur melalui proses yang sama dan berulang seperti di atas. Proses di atas merupakan proses yang normal dimana terjadi gerusan dan endapan pada dasar sungai dan tidak terpengaruh oleh perubahan akibat proses yang terjadi di pantai. Tidak terjadi endapan pasir di muara sehingga tidak akan terjadi penyumbatan muara yang dapat menyebabkan 
banjir. Studi mengenai teknik pantai dalam studi CDMP menyimpulkan bahwa tidak akan terjadi pergerakan muara kearah Utara, tetapi akan melebar kearah Timur dan Barat dengan volume angkutan sedimen pada kondisi saat ini, maka Selat Madura akan tertutup dalam waktu 200 tahun. (BBWSBS, 2012)

\section{Sub Bottom Profile (SBP)}

Sistem Sub Bottom Profile (SBP) terdiri dari sumber suara, baik ditarik di belakang kapal atau dipasang ke lambung, menghasilkan pulsa akustik yang diatur frekuensi, daya, dan durasi waktunya. Pulsa akustik yang dihasilkan dapat digambarkan sebagai single-beam. Pulsa akustik bergerak melalui kolom air (dipengaruhi oleh suhu air, sanilitas dan konsentrasi bahan tersuspensi) dan menembus dasar laut. Beberapa sinyal akustik dipantulkan dari dasar laut, sedangkan sisanya menembus dasar laut dan terpantulkan kembali ketika bertemu batas antara lapisan yang memiliki impedansi akustik yang berbeda. Impedansi akustik material ( $\mathrm{Z}$ ) tergantung pada densitas bulk basah sedimen $(\rho)$, dan kecepatan gelombang (c), dimana:

$$
Z=\rho \cdot c
$$

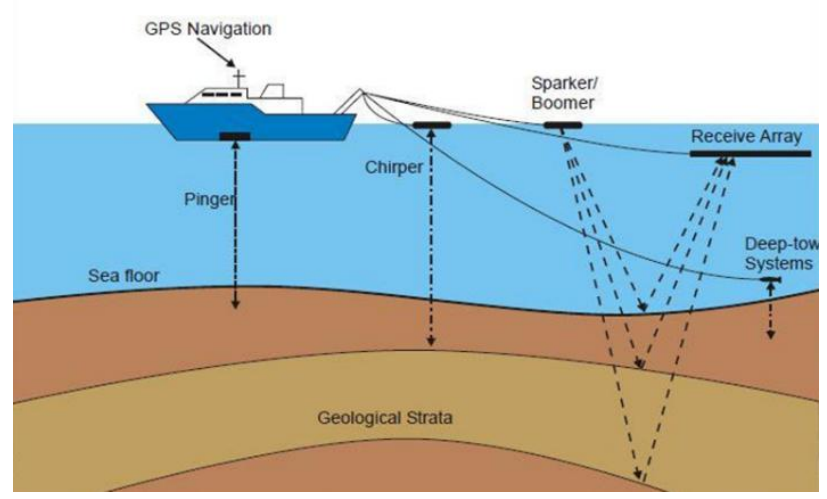

Gambar 2. Pemasangan Berbagai Sistem SBP (Penrose Et Al, 2005).

SBP memiliki banyak tipe, tipe dari SBP dapat dikategorikan menjadi sistem frekuensi tinggi (1-30 $\mathrm{kHz}$ ) dan sistem frekuensi tinggi tinggi yang menghasilkan profil resolusi rendah. Adapun contoh dari sistem frekuensi tinggi seperti sistem chirper dan pinger, sedangkan untuk frekuensi rendah seperti water dan air guns, sparkers, sleeve exploders, bibble pursers, dan boomers. Dalam sistem frekuensi rendah, sumber energi mentransmisikan sinyal berisi spektrum yang luas dan membutuhkan secara terpisah hydrophone array yang diderek untuk menerima sinyal pantulan. (Penrose et al, 2005)

\begin{tabular}{|c|c|c|c|c|c|c|}
\hline System & $\begin{array}{l}\text { Operating } \\
\text { frequency }\end{array}$ & $\begin{array}{l}\text { Acoustic } \\
\text { source }\end{array}$ & $\begin{array}{c}\text { Receive } \\
\text { array }\end{array}$ & $\begin{array}{l}\text { Typical } \\
\text { resolution }\end{array}$ & $\begin{array}{l}\text { Depth of } \\
\text { penetration }\end{array}$ & $\begin{array}{c}\text { Source } \\
\text { mounting } \\
\text { style }\end{array}$ \\
\hline Sparker & $\begin{array}{l}50 H z-4 \\
k H z\end{array}$ & $\begin{array}{l}\text { electrical } \\
\text { spark } \\
\text { in water }\end{array}$ & $\begin{array}{l}\text { towed } \\
\text { streamer }\end{array}$ & $<2 m$ & $500 \mathrm{~m}$ & towed \\
\hline Chirper & $\begin{array}{l}\text { swept } 1-10 \\
k H z\end{array}$ & $\begin{array}{l}\text { swept } \\
\text { frequency } \\
\text { transducer } \\
(1-10 \mathrm{kHz})\end{array}$ & transducer & $\sim 0.05 \mathrm{~m}$ & $<100 \mathrm{~m}$ & $\begin{array}{l}\text { hull } \\
\text { mounted } \\
\text { or towed }\end{array}$ \\
\hline & $\begin{array}{l}300 \mathrm{~Hz}-3 \\
\mathrm{kHz}\end{array}$ & $\begin{array}{l}\text { boomer } \\
\text { plate }\end{array}$ & $\begin{array}{l}\text { towed } \\
\text { streamer }\end{array}$ & $0.5-2 \mathrm{~m}$ & & $\begin{array}{l}\text { towed } \\
\text { sled }\end{array}$ \\
\hline Pinger & $\begin{array}{l}\text { tuned } \\
\text { between } 2- \\
12 \quad \mathrm{kHz}(\mathrm{eg} \\
3.5 \mathrm{kHz})\end{array}$ & $\begin{array}{l}\text { combined } \\
\text { piezo- } \\
\text { transducer/ } \\
\text { transceiver }\end{array}$ & $\begin{array}{l}\text { combined } \\
\text { piezo- } \\
\text { transducer/ } \\
\text { transceiver }\end{array}$ & $0.2 \mathrm{~m}$ & $10-50 \mathrm{~m}$ & $\begin{array}{l}\text { hull } \\
\text { mounted }\end{array}$ \\
\hline
\end{tabular}

Gambar 3. Karakteristik Sistem dari Berbagai Lelas SBP. (Penrose et al, 2005).

\section{Stratabox Marine Geophysical Instrument}

Stratabox merupakan alat portable yang memiliki resolusi tinggi, dengan daya yang rendah dan juga alat instrument geofisika ini merupakan alat yang anti air untuk menggambarkan profil sedimen bawah laut. Kedalaman penetrasi Stratabox mencapai 40 meter. Alat ini didesain untuk lokasi daerah darat dan daerah pantai yang tidak memiliki kedalaman air laut yang dalam.
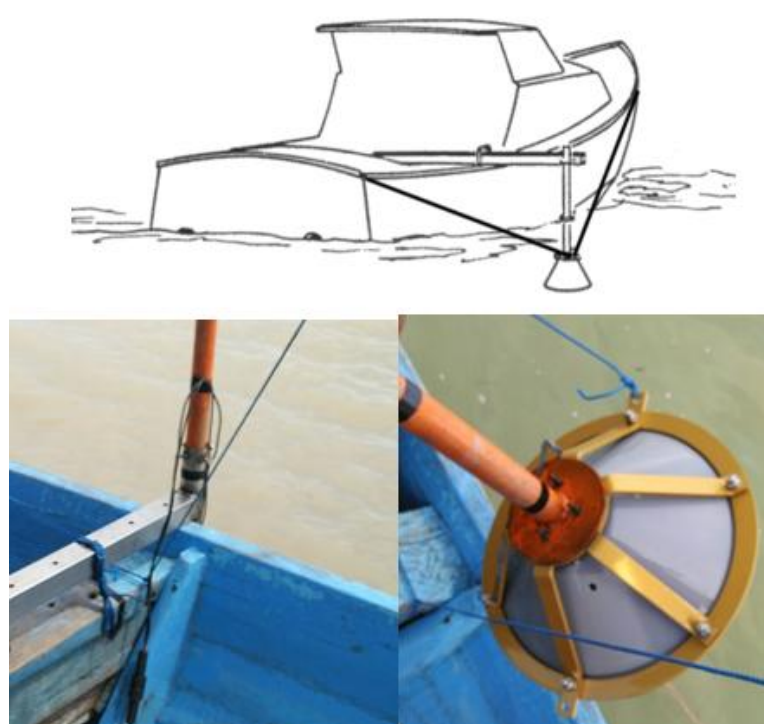

Gambar 3. Alat Stratabox untuk Akusisi SBP dan Batimetri. 


\section{METODOLOGI PENELITIAN}

Akusisi data lapangan dilakukan sebanyak dua kali, yaitu pada tanggal 25-27 Oktober 2016 dan 1-2 November 2016 di Ujung Pangkah ， Kabupaten Gresik, Jawa Timur . Lokasi penelitan berada pada koordinat $650.460^{\prime} \mathrm{S}$ dan $11232.425^{\prime} \mathrm{E}$. Sebagian besar lokasi penelitian merupakan daerah laut dangkal dikarenakan adanya sedimentasi yang cukup tinggi pada daerah tersebut.

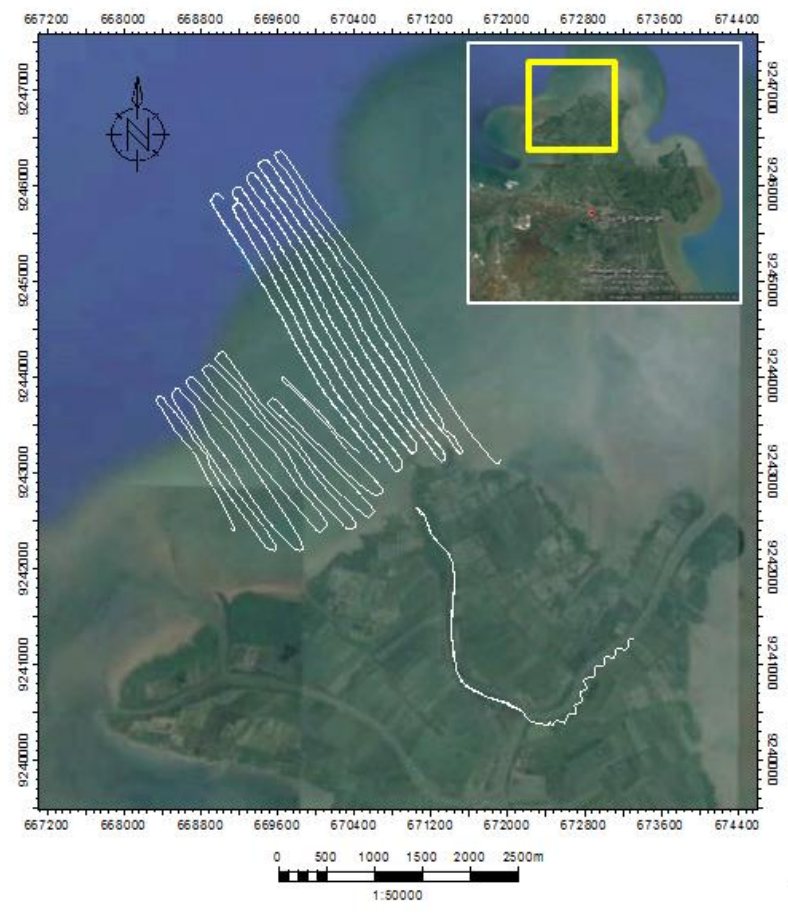

Gambar 4. Lokasi Penelitian dengan Lintasan Kapal Pengambilan Data SBP dan Data Batimetri.

(Google Earth, 2016).

Data yang digunakan pada penelitian ini sebanyak dua data, yaitu data SBP (Sub Bottom Profile) dan data batimetri. Tujuan dilakukannya akuisisi SBP yaitu untuk menganalisis ketebalan lapisan sedimen pada daerah penelitian. Akuisisi data SBP ini dilakukan dengan menggunakan perahu nelayan, kemudian alat Stratabox diletakkan di samping badan kapal, dengan parameter akusisi :
- Frekuensi
: 2-10 kHz
- Kedalaman transducer
: 0.4 meter
- Gain
: 5-15 dB

Kemudian dari akusisi data didapatkan 2 format data, yaitu .odc dan .segy, kemudian data tersebut diolah berdasarkan diagram alir sebagai berikut.

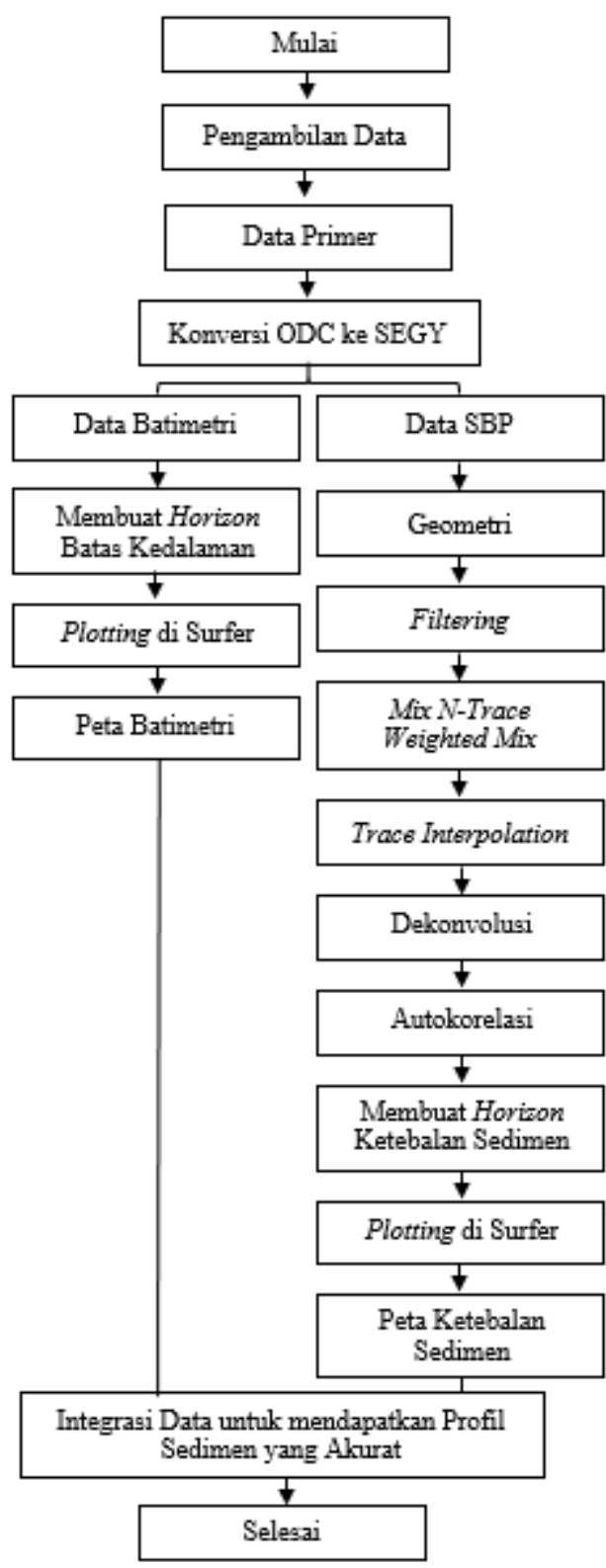

Gambar 5. Diagram Alir Pengolahan Data SBP dan Batimetri.

Terdapat 4 tahapan pengolahan data yang sangat penting yaitu di antaranya Filter Ormbsby, Mix N-Trace Weighted Mix, Trace Interpolation, dan 
Dekonvolusi. Filter bandpass digunakan untuk mereduksi noise yang terdapat pada data, parameter yang digunakan dalam filter ini yaitu:

$\begin{array}{ll}\text { - Low Truncation Freq } & : 300 \\ \text { - Low Cut Freq } & : 800 \\ \text { - High Cut Freq } & : 4000 \\ \text { - High Truncation Freq } & : 6000\end{array}$

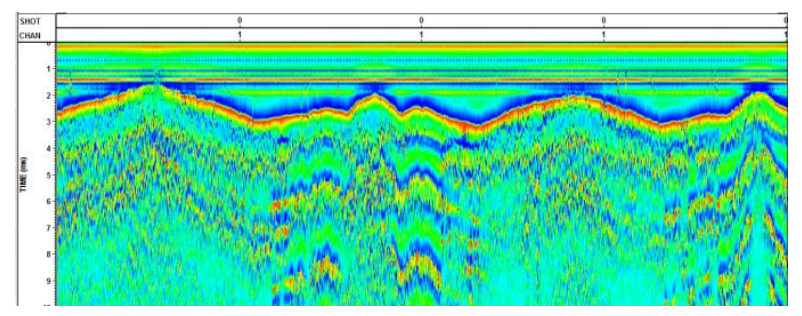

Gambar 6. Penampang SBP setelah Dilakukan Filter Ormbsy.

Pada data SBP banyak terdapat double shot atau multi shot dalam satu posisi, sehingga hal ini akan mengganggu proses pengolahan data. Maka tahapan selanjutnya setelah filtering yaitu Mix NTrace Weighted Mix. Kegunaan dari tahapan ini yaitu untuk menyatukan beberapa trace yang spesifik untuk menjadi satu trace dan juga untuk melakukan smoothing pada data.

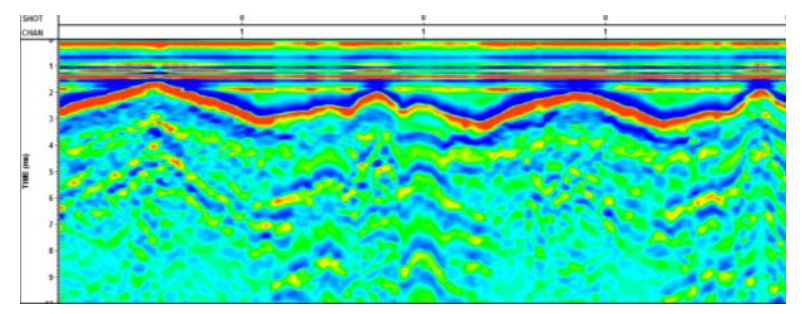

Gambar 7. Penampang SBP setelah Dilakukan Mix N-Trace Weighted Mix.

Pada Gambar 7 di atas, setelah dilakukan Mix NTrace Weighted Mix maka data penampang SBP lebih smooth dan juga lebih jelas kemenerusannya. Sehingga akan memperbaiki kualitas data. Kemudian tahapan selanjutnya adalah trace interpolation. Trace interpolation bertujuan yaitu untuk memberikan jarak pada masing-masing trace, pada tahapan ini parameter yang diberikan yaitu jarak antar trace yang baru adalah $10 \mathrm{~m}$.

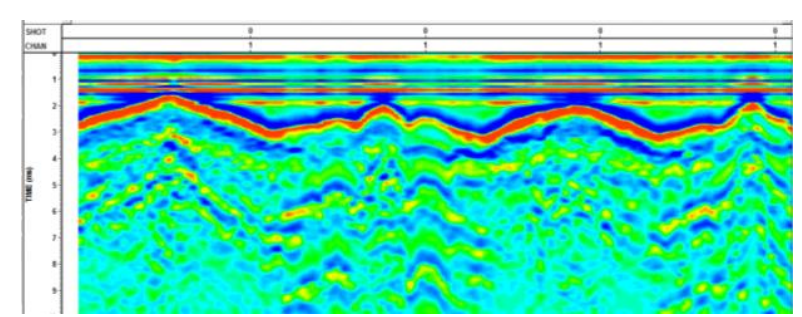

Gambar 8. Penampang SBP setelah Dilakukan Trace Interpolation.

\begin{tabular}{|l|c|c|c|r|}
\hline \multicolumn{1}{|c|}{ NAME } & 2D/3D & GEOMETRY & STACKED & TRACES \\
\hline [1]: 20161026075000-HF & 2-D & LAND & UNSTACKED & 40950 \\
\hline filter-ormsby_300-800-4000-8000 & 2-D & LAND & UNSTACKED & 40950 \\
\hline wghtmix_(mix-interpolate)-fix & 2-D & LAND & UNSTACKED & 40950 \\
\hline trace_interpolation_(mix-interpolate)-fix & 2-D & LAND & UNSTACKED & 4095 \\
\hline
\end{tabular}

Gambar 9. Perbandingan Jumlah Trace Sebelum dan sesudah Dilakukan Trace Interpolation.

Pada Gambar 9 di atas ditunjukkan bahwa setelah dilakukan trace interpolation, maka jumlah trace akan berkurang 10 kali lipat dari jumlah trace awal. Sebelum dilakukan interpolasi jumlah trace sebanyak 40950, kemudian setelah dilakukan interpolasi jumlah trace menjadi 4095. Kemudian tahapan selanjutnya yaitu dekonvolusi. Dekonvolusi adalah suatu proses utuk menghilangkan pengaruh dari wavelet sumber dari suatu trace seismik. Pada penelitian ini digunakan prediktif dekonvolusi, diharapkan dekonvolusi mampu menekan reverbrasi (perulangan) yang terdapat pada data seismik dan juga untuk memperbaiki resolusi data. Prediktif dekonvolusi menggunakan parameter GAP dan operator length yang berbeda. GAP adalah lebar defleksi yang lolos, yaitu satu gelombang. Kemudian operator length adalah lama reverbrasi. Digunakan parameter GAP $0.2 \mathrm{~ms}$ dan operator length $1.2 \mathrm{~ms}$.

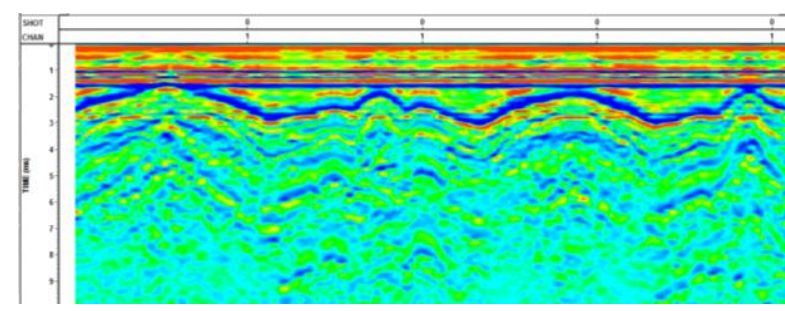

Gambar 10. Penampang SBP setelah Dilakukan Prediktif Dekonvolusi. 
Untuk quality control (QC) dari dekonvolusi ini digunakan autokorelasi. Autokorelasi adalah perkalian kepada dirinya sendiri. Hal ini digunakan untuk mengetahui similaritas dari suatu fungsi atau pola berulah pada sinyal. Sehingga, saat similaritas makin besar (mendekati 100\%), maka hal ini menunjukkan semakin kecilnya reverbrasi, seperti yang ditunjukkan pada Gambar 11 di bawah ini.

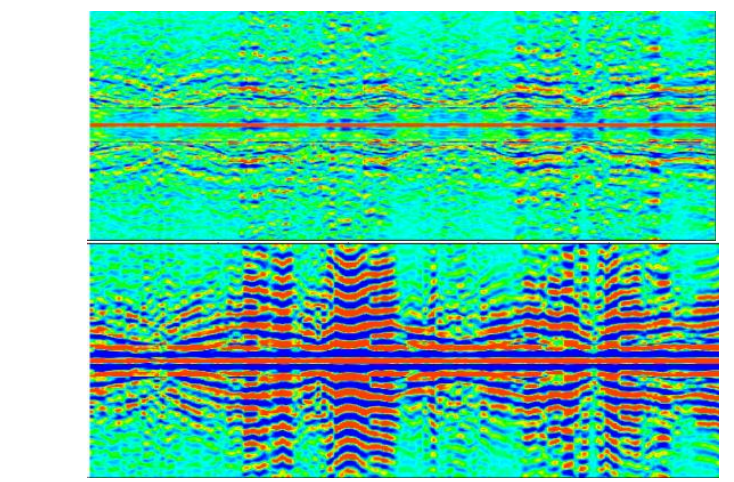

Gambar 11. Autokorelasi Setelah (Atas) dan Sebelum (Bawah) Dilakukan Prediktif Dekonvolusi.

\section{HASIL DAN PEMBAHASAN}

\section{Analisis Batimetri Muara Sungai Bengawan Solo}

Berdasarkan peta surface 2D dapat dianalisa bahwa kedalaman muara sungai berkisar antara 0.3 - 7 meter. Analisa batimetri dibagi menjadi tiga bagian yaitu pada bagian muara sungai menuju ke Laut Jawa, mulut muara dan badan sungai.

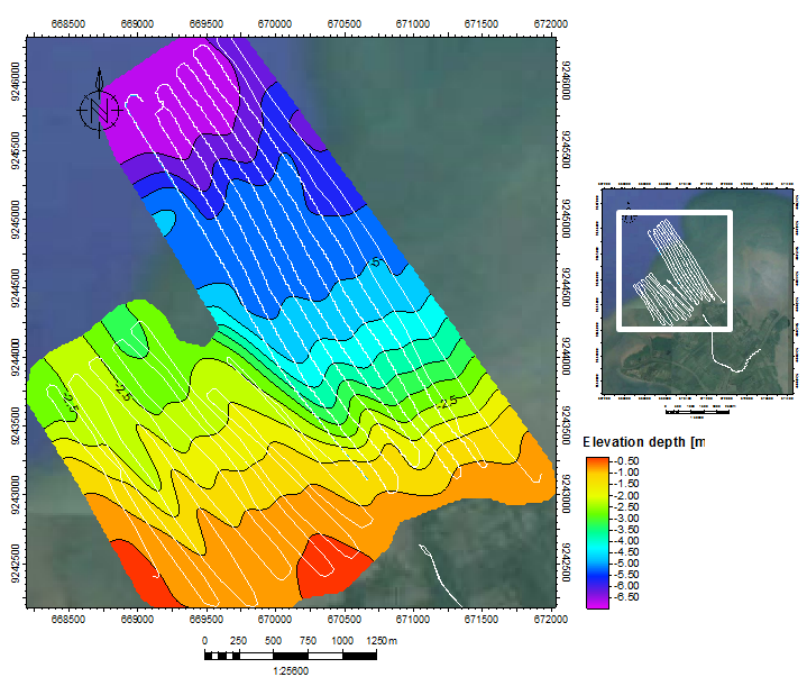

Gambar 12. Peta Batimetri pada Muara Sungai Menuju ke Laut Jawa.
Pada Gambar 12 di atas merupakan bagian muara sungai menuju ke Laut Jawa, kedalaman daerah ini cukup dalam hingga 7 meter. Lokasi ini sering digunakan nelayan mencari ikan dengan cara membuat jebakan jaring pada beberapa lokasi. Pada daerah ini kedalaman laut mulai dari 0.5 - 7 meter dengan ditunjukkan warna merah hingga biru pada Gambar 12 tersebut. Kemudian pada bagian merah merupakan daerah mulut muara. Lokasi ini mengalami pendangkalan yang semakin berjalannya waktu semakin meningkat. Sehingga bagian mulut muara ini tidak dapat di lewati nelayan jika air sudah tidak pasang lagi. Kedalaman mulut muara berkisar $0.3-0.8$ meter.

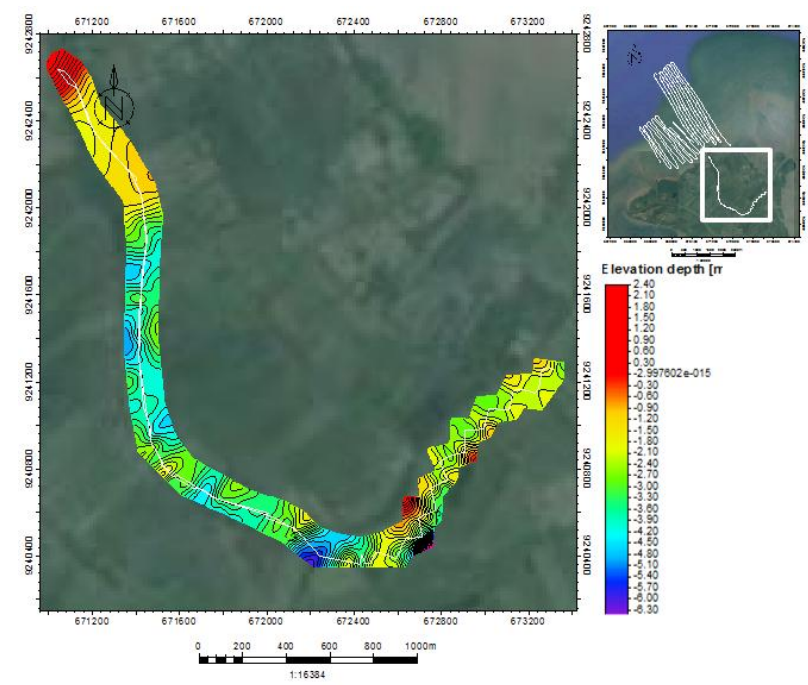

Gambar 13 Peta Batimetri pada Cabang Sungai Bengawan Solo Bagian Tengah.

Kemudian selanjutnya dilakukan analisa batimetri pada bagian badan sungai. Kedalaman Sungai Bengawan Solo berdasar Gambar 13 di atas sekitar 0.5 - 6 meter. Kedalaman 0.5 meter berada di daerah mulut muara sungai bengawan solo. Kemudian kedalaman 6 meter berada di daerah percabangan antar sungai.

\section{Analisis Ketebalan Sedimen Muara Sungai}

Pada Gambar 14 di bawah, menunjukkan persebaran ketebalan sedimen pada sungai Bengawan Solo yaitu sekitar 1 meter. Ketebalan sedimen pada sungai di kontrol oleh laju sedimentasi dari Sungai Bengawan Solo itu sendiri. Saat arus sungai deras maka laju sedimentasi akan 
sedikit, namun jika arus sungai melambat maka laju sedimentasi akan meningkat. Hal ini dikarenakan saat arus sungai melambat, material sedimen akan terendapkan dengan perlahan ke dasar sungai.

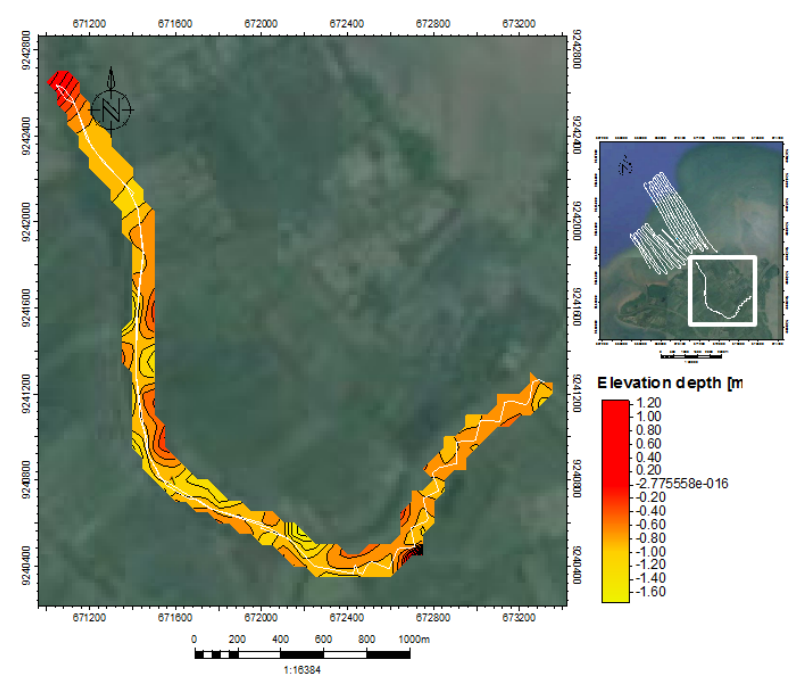

Gambar 14. Peta Ketebalan Sedimen pada Muara

Sungai Bengawan Solo.

Kemudian dilakukan juga analisa ketebalan sedimen pada bagian muara menuju ke Laut Jawa. Seperti yang ditunjukkan pada Gambar 15 di bawah ini. Gambar di bawah ini menunjukkan ketebalan sedimen pada muara Sungai Bengawan Solo sekitar kura lebih 1 meter.

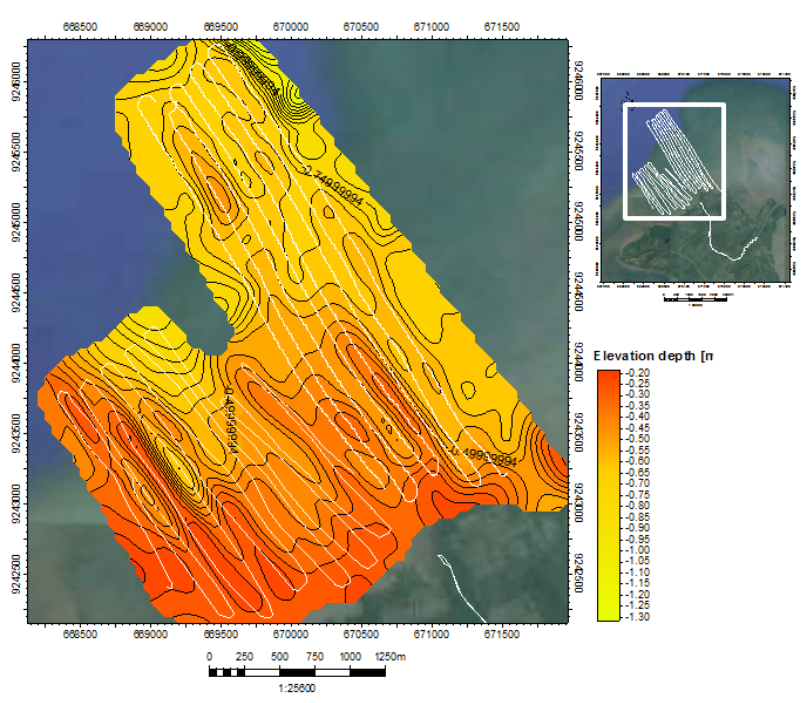

Gambar 15. Peta Ketebalan Sedimen pada Bagian Muara Menuju Ke Laut Jawa.
Dari analisa peta ketebalan bagian sungai dan bagian muara menuju ke laut, dapat disimpulkan jika persebaran ketebalan sedimen pada muara Bengawan Solo yakni kurang lebih 1 meter. Semakin menuju ke laut, maka ketebalan sedimen akan semakin menebal. Untuk lebih menguatkan analisa, maka dilakukan pengamatan lapangan. Pengamatan di lapangan yang dilakukan adalah melihat sekitar kondisi sungai, seperti pada Gambar 14 di bawah ini.

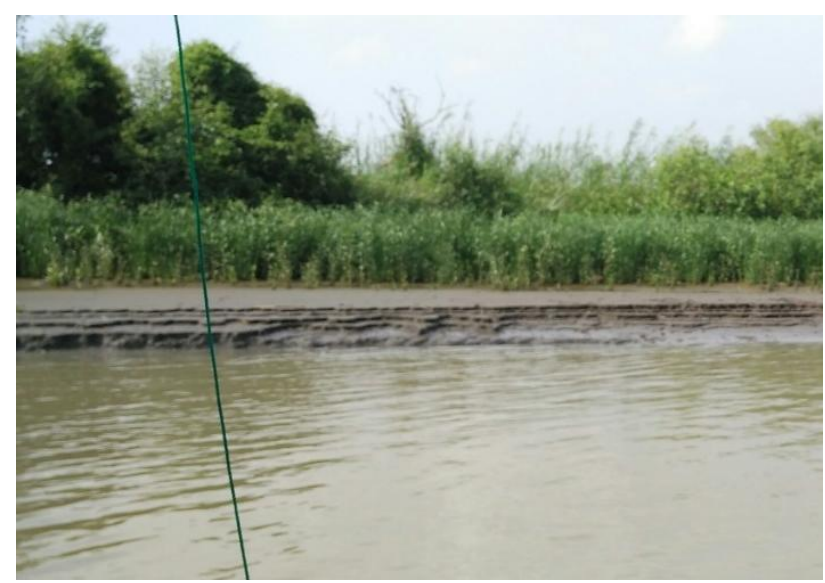

Gambar 16. Ketebalan Sedimen pada Pinggir Sungai.

Sedimentasi pada bagian dinding sungai yang terlihat pada Gambar 16 cukup tebal. Foto ini diambil pada bagian sungai Bengawan Solo, pada Gambar 16 terlihat lapisan sedimen seperti berlapis-lapis. Lapisan - lapisan ini menunjukkan waktu material sedimen tersebut terendapkan. Satu lapisan menunjukkan waktu pengendapan sedimen yang sama. Sehingga hal ini memperkuat analisa bahwa adanya sedimentasi yang cukup tinggi pada Sungai Bengawan Solo.

\section{PENUTUP}

\section{Kesimpulan}

Kesimpulan yang didapat dari penelitian ini antara lain.

1. Berdasarkan data SBP, maka ketebalan sedimen di Muara Sungai Bengawan Solo kurang lebih 1 meter.

2. Berdasarkan data SBP pada muara sungai, dapat diidentifikasi kedalaman Muara Sungai Bengawan Solo yaitu $0.3-8$ meter. 


\section{Saran}

Saran yang dapat diberikan yaitu perlu adanya kontrol kedalaman air laut dengan menggunakan echosourder sehingga didapatkan angka kedalaman yang lebih akurat.

\section{Ucapan Terima Kasih}

Penulis mengucapkan terima kasih kepada dosen-dosen pembimbing Bapak Dwa Desa Warnana dan Pak Firman Syaifuddin atas ide penulisan dan pengarahannya selama proses penelitian hingga penulisan

\section{DAFTAR PUSTAKA}

Amri, Ulil., 2016. Integrasi Data SBP dan Gravity Core untuk Menentukan Dinamika Sedimentasi Resen di Perairan Utara Wokam: Institut Pertanian Bogor.

Lurton, X., 2002. An Introduction to Underwater Acoustic. Springer, Praxis. Chichester, UK.

Penrose dkk., 2005. Acoustic Techniques for Seabed Classification: Cooperative Research Centre for Coastal Zone Estuary and Waterway Management.

Sun, Y., Y. Gao, P. Yan, J. Wang, W. Yuan, H. Wub, Y. Wang, P. Wan, and G Zhao., 2009. Development of a 20 kJ Sparker for High Resolution Ocean Seismic Survey. Acta Physica Polonica, 115:10591061.

SyQwest., 2016. StrataBox Marine Geophysical Instrument: Syqwest Incorporated.

Wang, J. and Sacchi, M., 2009. Noise Reduction by Structure and Amplitude Preserving Multichannel Deconvolution. CSEG recorder.

Yilmaz, O., 2001. Seismic Data Analysis Processing, Inversion, and Interpretation Seismic Data. Society Exploration Geophysicists, USA. 